\title{
Digital Media and Counter-Narrative of Radicalism
}

\author{
Athik Hidayatul Ummah \\ Universitas Islam Negeri Mataram, Indonesia \\ e-mail: athika_hidayah@uinmataram.ac.id
}

\begin{abstract}
This article aims to describe the meaning of narratives are used by digital media or online media to counter the narrative of radicalism. The research method used is discourse analysis to find the meaning in the text. The theoretical framework used is narrative theory to explain process audience can trust abouta narrative because of the consistency and truth of narrative or story. Narratives are analyzed using a framework of identity prism theory. The identity prism describes that online media as a brand has a strategy to build and promote it is unique among other brands. The results of the study are Islami.co and Ruangobrol.id have different characteristics or uniqueness and segmentation to convey the counter-narratives to the public. The narratives are built is to fight or deconstruct the narratives of radicalism-terrorism as an effort to prevent radicalism and the recruitment of new members through the internet. The counter-narrative also has coherence and truth as important standards for the public to select and judge that the narrative is consistent and credible. In the digital age, digital media have an important role to counternarratives of radicalism. It's because radical-terrorist groups using the internet and social media platforms to spread their thoughts and their actions.
\end{abstract}

Keywords: Counter-Narrative; Digital Media; Narrative Theory; Radicalism

\section{A. Introduction}

Today, the variety of religious discourses fulfil in digital media. Radicalism is one of the topics that often discussed in religious studies. Especially the emergence of thoughts and actions of radicalism that are widespread in cyberspace. During the Covid-19 pandemic, the people were getting closer to the internet. Almost all activities use the internet, including seeking da'wah content or religious studies. According to the BNPT, in this condition, the efforts of terror groups to spread their propaganda, recruitment, and funding increasingly massive in cyberspace. This is influenced by the evolution of information technology and social media. ${ }^{1}$

1BNPT, "Waspadai Aktivitas Terorisme Di Ruang Siber," 2020, https://bnpt.go.id/ waspadai-aktivitas-terorisme-di-ruang-siber-deputi-bidang-penindakan-dan-pembinaan-

JURNAL THEOLOGIA - Volume 31, Nomor 2, Desember 2020 
Regarding the content of radicalism and terrorism has spread on the internet, Kominfo from 2017 to July 2020 has blocked 16,739 content. The most blocked content is on Facebook with 11,600 content. Then Twitter 2,282 content, website 496 content, Youtube 678 content, and File-sharing about 1,000 content. $^{2}$ The internet and social media was a strategic choice for radical and terrorist groups as channels to spread their propaganda messages and radicalism. Radical and terrorist groups can understand trends in human life. They use the internet as an effective propaganda tool to get support from sympathizers. Besides, internet networks can also replace the role of mainstream media that radical-terrorist groups cannot have. ${ }^{3}$

The trend of radicalism in Indonesia tends to increase. The Wahid Foundation and LSI survey results (2016) show that $0.4 \%$ (around 600,000 people) have ever done radical actions and $7.7 \%$ (11.4 million people) are prone to be affected by radicalism if they are invited and they have the opportunity. Meanwhile, the results of research of the Center for Islamic and Community Studies (PPIM) of UIN Syarif Hidayatullah and Convey Indonesia (2017) show that 58.5\% of students have religious views that tend to be intolerant or radical; $37.71 \%$ agree that Jihad is a form of war against nonMuslims; $86.55 \%$ agree if the government prohibits minority groups who deviate from Islamic teachings; $91.23 \%$ agree that Islamic law needs to be implemented in the state. Also, $54.8 \%$ of young people or millennials like to search religious knowledge through the internet (blogs, websites and social media); $48.57 \%$ through books, and 33.73\% through television channels. They have the potential to be intolerant and radical because they are the largest internet users compared to the other age groups.

The enthusiasts of radicalism thought and action more and more because the source of religious understanding in the digital era can be obtained easily and independently, without teachers. This is strengthened because of the

kemampuan-bnpt-sepakati-perjanjian-kerja-sama-dengan-direktorat-jenderal-aplikasiinformatika-kemkominfo.

${ }^{2}$ Kominfo, "Pemblokiran Dan Literasi Jadi Langkah Kominfo Cegah Terorisme Di Ruang Digital,” 2020, https://aptika.kominfo.go.id/2020/08/pemblokiran-dan-literasi-jadi-langkahkominfo-cegah-terorisme-di-ruang-digital/.

3 Benedicta Dian Ariska Candra Sari, "Media Literasi Dalam Kontra Propaganda Radikalisme Dan Terorisme Melalui Media Internet," Peperangan Asimetrik 3, no. 1 (2017). 
ease of internet access that can connect anyone and anywhere in the world. If religious references on the internet are dominated by radical religious views groups, then the cultivation of self-righteous norms, war against non-Muslims is jihad, and another doctrine can reach internalization stages of fanatical Islam through cyberspace.

The internet and social media are sources of uncontrolled information strictly, so that can leads to closed religious attitudes, intolerant, violent extremism, then become radicalized and involved in acts of terrorism. Through information search engines, some sites on the internet and social media platforms, extreme thoughts and attitudes are presented and spread massively. For example, Mortem Storm, a radical turned as a government spy. According to him, the books, teachings and late-night conversations led him to become militant and radical. Not only that, the spectacle of the battlefield also creates a sense of solidarity with radical groups. ${ }^{4}$

Extreme and radical attitudes do not appear due to a single factor, but there are various factors. One of them because of the openness of access to information through various digital media platforms. Radical ideologues and recruiters are well aware of this technological opportunity. They actively manage spaces for disseminating information to spread radical ideology and mobilize followers or sympathizers. According to the INFID report, 5 this condition inversely proportional with the moderate and secular groups that they do not pay attention seriously to the opportunities of technological innovation. The moderate group is not ready to face the wide penetration of information technology that has been used massively for radicalism.

Radical groups create radical narrative content rapidly in cyberspace. Some propaganda messages are offered by radical groups, such as the destruction of nature and social order because the capitalist system; Muslims have been far from religious teachings; Islam was colonized and oppressed; democracy is a bad system; solutions to establish a caliphate system (Khalifah)

${ }^{4}$ Donald Holbrook, "What Types of Media to Terrorists Collect?: An Analysis of Religious, Political and Ideological Publications Found in Terrorism Investigations in the UK," ICCT Research Paper, 2017.

5 INFID (International NGO Forum on Indonesian Development), Urgensi Dan Strategi Efektif Pencegahan Ekstrimisme Di Indonesia (Jakarta: INFID, 2018), 48.

JURNAL THEOLOGIA — Volume 31, Nomor 2, Desember 2020 
to lead Muslims worldwide; only Islamic ideology is worthy of being the basis for the struggle and jihad; rejecting non-Muslim leaders; infidels as enemies, and others. Meanwhile, the counter-narrative content of radicalism in cyberspace has not been fully spread massively.

This article aims to find out the narrative text that used by digital media, in this case, is Islami.co and Ruangobrol.id, to counter the narrative of radicalism. This research is expected to contribute to the field of communication, especially in-depth understanding of narrative theory and communication to prevent radicalism and terrorism. This study is also expected to be an input for the government, community organizations, educational institutions, media institutions, or individuals to fight against radicalism groups by reading trends in social life.

The method of data analysis in this research is discourse analysis. Discourse analysis is used to examine in depth to know the meaning in the text. The narrative is a way to discuss and understand reality and to construct meaning in a social context. There are three dimensions for analyzing the meaning in a text, including the text dimension, the discourse dimension, and the social practice dimension. ${ }^{6}$ And then, to strengthen this study, a literature review is used to view previous studies for comparison and research gap.

The research data were obtained by analyzing the text of the narratives that create by Islami.co and Ruangobrol.id. There are four texts were analyzed in this study. Two texts from Islami.co, are text of "religion with love" and text of "tolerance is active, not passive". And then two texts from Ruangobrolid, are the text of "from cool to slipping radical groups" and text of "tolerance from childhood". The texts were selected based on the theme about counternarrative of radicalism, and Islami.co or Ruangobrolid have almost the same title text. The basic consideration for choosing the Islami.co and the Ruangobrolid is because they have a vision and mission and concern on the issue of counter-radicalism. Both of them have different backgrounds, positioning and segmentation so that this study can compare the narrative of two digital media.

${ }^{6}$ Norman Fairclough, Analysing Discourse: Textual Analysis for Social Research (Psychology Press, 2003), 2. 


\section{B. The Power of Digital Media and Online Radicalization}

The digital era has an impact on the religious way of the society, including affiliation with religious institutions is fading; traditional religious authority turns into new religious authority through impersonal media (such as websites, blogs, Youtube, Facebook, Instagram, and others); individualism is getting stronger, and pluralism or diversity turns into tribalism. The availability of the internet for individuals and religious groups opens up new spaces not only for communication consumption but also for the production of religious content. ${ }^{7}$

The revolution in information and communication technology, especially the internet and social media networks, has helped terrorist groups reproduce their ideas and thoughts, and further expand their networks. Since 1998 there are an estimated 12 terrorist group sites on the internet, five years later, it shot up to 2,650 sites in 2003, and in 2014 more than 9,800 sites were found. ${ }^{8}$ The process of disseminating radicalism is currently faster, has a wider reach, and it is quite difficult to detect who the 'actor' is behind it. This spread of radicalism is not only from the top-down and bottom-up, but it is allowed to spread by itself through the internet network. ${ }^{9}$

Before the internet existed, the main factor in the spread of radicalism was face-to-face interaction and the closest relationship as kinship, family and friendship. However, these factors are no longer strong to be the main factor in today's digital era. The spread of radicalism through the internet is a major factor why radicalism faster spread. ${ }^{10}$ The paradigm of the radicalismterrorism network has changed. Technology advances contradict with the characteristics of radical groups that are conservative, anti-modernization, and anti-democratic. However, they intensively, systematically, and enthusiastically use digital media and the internet effectively to carry out their

${ }^{7}$ Heidi Campbell, When Religion Meets New Media (London: Routledge, 2010), 24.

${ }^{8}$ Gabriel Weimann, Terror on the Internet: The New Arena, the New Challenges (US Institute of Peace Press, 2006), 30.

${ }^{9}$ Syarif Saddam RivanieParawansa, Koesrianti, and Toetik Rahayuningsih, "Prevention of Radicalism in the Cyberspace in Indonesia," International Journal of Humanities Social Sciences and Education (IJHSSE) 6, no. 7 (2019): 63-72.

10 Philip Seib and Dana M Janbek, Global Terrorism and New Media: The Post-Al Qaeda Generation (Routledge, 2010), 19.

JURNAL THEOLOGIA — Volume 31, Nomor 2, Desember 2020 
propaganda. They use digital media as 'wars' to win the hearts and minds of the people.11

Radicalism is an understanding that requires total change or replacement of a condition or system in social life. The radical group considers that their understandings and actions are the truest and ideal way. They show that extreme attitudes as an excuse for change amid conditions of poverty, social inequality, and injustice. Radicalism also often creates a narrow understanding of the name of religion and leads to terrorist bombings. So, radicalism does not always mean terrorism, but it can be the seed for the emergence of intolerance, extremism and terror. ${ }^{12}$

The internet and social media as the strategic medium and the instruments of most terrorist groups' actions. Terrorist groups use the internet to carry out their goals, including: as networking, propaganda, recruitment of members or sympathizers, training and financing. ${ }^{13}$ It means that terrorist groups have successfully "read" and take the strategic opportunity that internet networks and social media platforms can radicalize people's minds and attitudes. So how can someone become radical by accessing the internet and social media?

The online radicalization can be interpreted as a process where a person through online activities can interact using various facilities on the internet, then he accepts the understanding that violence is the right method to solve problems, especially related to social and political conflicts. ${ }^{14}$ The action pattern of radical-terrorist groups is by spreading the ideology through the internet or website portals, utilizing interactive communication features such as chatrooms, and using social media as propaganda such as Facebook, Twitter, and Youtube. 15

11 Achmad Zainal Huda, "Melawan Radikalisme Melalui Kontra Narasi Online," Journal of Terrorism Studies 1, no. 2 (2019): 1.

${ }^{12}$ Sunyoto Usman, Zuly Qodir, and J Hasse, Radikalisme Agama Di Indonesia (Yogyakarta: Pustaka Pelajar, 2014), 24.

13 Maura Conway, "Determining the Role of the Internet in Violent Extremism and Terrorism: Six Suggestions for Progressing Research," Studies in Conflict \& Terrorism 40, no. 1 (2017): 77-98.

14 Anita Perešin, "Al-Qaeda Online Radicalization and the Creation of Children Terrorists," Medijska Istraživanja: Znanstveno-Stručni Časopis Za Novinarstvo i Medije 20, no. 1 (2014): 85-101.

${ }^{15}$ Agus Surya Bakti, Deradikalisasi Dunia Maya: Mencegah Simbiosis Terorisme Dan Media (Daulat Press, 2016). 
The internet and social media are effective channels for searching religious understanding and can radicalize internet users. As experienced by "Duo Siska", two students who were arrested by the Special Anti-terror Detachment because they wanted to jihad at the Police office. Duo Siska study extremism via the internet and social media. The campaigns or messages of radical networks are spread on the internet and social media massively and can attract large audiences. The campaign is carried out in various forms, such as articles, videos and conversations through groups on chat platforms such as WhatsApp and Telegram. ${ }^{16}$

The process of radicalization through the internet initially spreads sympathy for internet users to groups experiencing injustice. After they are sympathetic, they can support and give donations. They can also download reading materials about these groups. Then join to chatrooms with various discussions themes and call to radical action. It is the seeds of radicalization can be spread widely. Thus, the internet facilitates the spread of extremist ideas and online brainwashing dialogues. This modern radicalization targets internet users regardless of education level, economic status, or gender. Like ISIS, which is very advanced in creating a global network model through virtual networks. Various manoeuvres and actions are carried out using technology and social media. Even the bombers of the 2013 Boston marathon admitted that they learned how to make bombs from al-Qaeda's online magazine "Inspire".17

The internet has a role in spreading radical Islamic ideas and sentiments that have been carried out by radical-extremist groups. The existence of jihad operations and narratives or news about jihad in the international world and in Indonesia that was built by 14 radical website portals in Indonesia, including Arrahmah. ${ }^{18}$ This shows how the development of the Internet in Indonesia, the influence and achievements of websites to form a radical narrative.

\footnotetext{
${ }^{16}$ Majalah Tempo, "Paham Radikal di Kampus Kita”, Investigasi majalah.tempo.co Edisi 28 Mei-3 Juni 2018.

17 Maeghin Alarid, "Recruitment and Radicalization: The Role of Social Media and New Technology," Impunity: Countering Illicit Power in War and Transition, 2016, 313-30.

${ }^{18}$ Jennifer Yang Hui, "The Internet in Indonesia: Development and Impact of Radical Websites," Studies in Conflict \& Terrorism 33, no. 2 (2010): 171-91.
}

JURNAL THEOLOGIA — Volume 31, Nomor 2, Desember 2020 
One pattern of acts of terrorism in Indonesia uses cyberterrorism is the use of computers and internet networks by terrorist groups in carrying out their actions such as using the internet for the radicalization process. The power of the internet lies in its paradoxes and contradictions. According to Jeff Zaleski, cybercasts, cyberreligionists, cyber programmers are optimistic that the new reality of cyberspace can replace existing realities and become a kind of new religion, new spirituality, and a new God. The internet can be used as a means of disseminating religious teachings, communication between religious communities, and even as a channel for spiritual energy. ${ }^{19}$

Many of these extremists use the internet to spread the ideology of jihad. So far, acts of terrorism, conflicts between religious communities, violence in the name of religion, violence against minorities, have made the internet as one of the media used to convey their ideas, views and actions. ${ }^{20}$ In the digital era, many people express their opinions and interpretations about Islam or matters related to Islam via the internet and social media. So, the impact is that various kinds of religious views and materials can easily be obtained on the internet, without knowing the source of their truth or their scientific nature. This is called virtual Islam.

The ideas, thoughts and actions of radicalism that have emerged on social media networks such as Facebook, Whatsapp, and Youtube are new spaces for propaganda, recruitment, training, and so on. This modern strategy seems to be effective in influencing audiences, especially the young generation of millennials who are the biggest internet and social media users. It means that the internet has become a fertile virtual field for radical groups to open networks and recruitment in cyberspace.

The cyberspace has become an important part in shaping the thoughts, behaviour, basic needs and lifestyle of modern humans today. For the millennial generation, the cyberspace is a space for socialization, individualization, and expression of piety or godliness. The complexity and variety of religious expressions on the internet also show overlapping issues such as

\footnotetext{
${ }^{19}$ Iman Fauzi Ghifari, "Radikalisme Di Internet," Religious: Jurnal Studi Agama-Agama Dan Lintas Budaya 1, no. 2 (2017): 123-34.

${ }^{20}$ Fazlul Rahman, "Kekerasan Atas Nama Tuhan: Respons" Netizen" Indonesia," Jurnal Indo-Islamika 1, no. 2 (2012): 197-231.
} 
evasion of religious authority, the image of a pluralistic society, conservatism, and transnational religious phenomena. ${ }^{21}$

The internet has a big role in providing information to the public, especially the younger generation regarding radical ideologies. ${ }^{22}$ This can be correlated with the fact that many young people are being recruited into radical group networks via the internet. It means that radical-terrorist organizations use internet technology to spread propaganda and recruit members. But on the other hand, the internet and social media also be used as a medium to fight radicalism by creating balanced information or counternarratives of radicalism to the public. It's important as a preventive effort against radicalism.

\section{Strategy of Communication and Counter-Narrative}

The narrative is a form of discourse is constructed purposely by actors to provide a description of the past, present, and future. Narrative strategies are created to target audience feelings about an incident or problem, and they can direct their behaviour softly according to their goals and expectations. ${ }^{23}$ For example the narrative of the Salafi jihadi group. First, they describe the Muslim world experiencing chaos due to non-Muslims (Zionists). Second, they offer change and a better world. They offer an alternative vision to provide a better and ideal social life order with a caliphate system (Khalifah) that regulated in accordance with the Shari'a to replace a corrupt regime, and so on. Third, the way is taken to realize this vision is jihad with violence.

The narrative as an ideology was built and promoted in the form of messages sent to the public. The messages are then translated, inspire and get various feedback from the public. Terrorist groups have even recognized the power and effectiveness of new media technology, especially social media, as an important platform for transmitting their narratives to a global audience. ${ }^{24}$

\footnotetext{
21 Leonard Epafras, "Religious E-Xpression among the Youths in the Indonesian Cyberspace," 2016.

${ }^{22}$ Leni Winarni, "Media Massa Dan Isu Radikalisme Islam," Jurnal Komunikasi Massa 7, no. 2 (2014): 159-66.

${ }^{23}$ Alister Miskimmon, Ben O'Loughlin, and Laura Roselle, Forging the World: Strategic Narratives and International Relations (University of Michigan Press, 2017).

${ }^{24}$ Cristina Archetti, "The Al Qaeda Narrative as a Brand," in Understanding Terrorism in the Age of Global Media (Springer, 2013), 144-68.
}

JURNAL THEOLOGIA — Volume 31, Nomor 2, Desember 2020 
The narrative of radicalism will be very dangerous if it is accepted by someone with an identity crisis. ${ }^{25}$ The biggest threat is not the number of followers of radicalism and terrorism, but the threat is a global information technology and mass media if it is not properly controlled by the government.

The internet and social media have created new opportunities for radical-terrorist groups to propagate their narrative. The influence of narratives accessed via the internet or social media independently is enormous. Online communication is very strategic to influence a wider audience because it allows users to easily connect with others, consume, produce, discuss, and distribute content quickly. One of the strategies against radicalism-terrorism thought and behaviour is through the counter-narrative of radicalism. This is important to balance the radical narrative that has been created by radical groups so that the messages are not accepted easily by the audience. Counter-narrative can be created with various scenarios presented by a person, group or community, mass media or online media, or the government. So, counter-narrative is the essence of the communication strategy.

The concept of counter-narrative has been used more broadly as a communication strategy or message delivery strategy to counter extremism group narratives and involves various actors (state and non-state). ${ }^{26}$ Counternarrative discourse is built to reject, reframe, divert, subvert other discourses that are competing or have mastered discursive power. ${ }^{27}$ Counter-narrative through digital media or online media emerged as a reaction to the spread of radical messages, propaganda, and recruitment of radical groups massively in the cyberspace. The assumption is the internet as an effective network to nourish the phenomenon of radicalism. Thus, the internet has an important role in conveying the counter-narrative of radicalism in cyberspace. ${ }^{28}$ Alvabet, 2012).

${ }^{25}$ Sarlito Wirawan Sarwono, Terorisme Di Indonesia: Dalam Tinjauan Psikologi (Pustaka

${ }^{26}$ Rachel Briggs and Sebastien Feve, "Review of Programs to Counter Narratives of Violent Extremism," 2013.

27 Michele Grossman, "Disenchantments: Counterterror Narratives and Conviviality," Critical Studies on Terrorism 7, no. 3 (2014): 319-335.

28 Omar Ashour, “Online De-Radicalization? Countering Violent Extremist Narratives: Message, Messenger and Media Strategy," Perspectives on Terrorism 4, no. 6 (2010): 15-19. 
There are several categories of counter-narrative. ${ }^{29}$ First, counternarrative messages are a strategy to communicate directly or indirectly to challenge extremist narratives through ideology, logic, facts or humour. The counter-narrative is targeted at audiences who are in the circle of radicalism, like sympathizers, passive supporters, and active in extremist groups. For example the "say no to terror" campaign as an online counter-narrative via Twitter, Facebook and Youtube.

Second, an alternative narrative is an online strategic communication to weaken extremist narratives by focusing on "what we are for" and not "what we are against". 30 Alternative narratives seek to influence sympathizers (but not actively support) to extremists or help unite the silent majority against extremism by emphasizing solidarity and shared values. The main purpose is to project a positive discourse, highlighting values such as democracy, freedom, rule of law, equality and respect for human rights. For example, the 'dare to be grey' campaign as an initiative to stop polarization that divides society through various social media platforms.

Third, government narrative or strategic communication. As the term implies, it is inherently the government's domain. It involves strategic communication efforts that ensure that government policies and positions are clearly articulated and directed to the right audience to help strengthen government efforts to build relationships with constituencies, and sometimes to counter misinformation about government policies and actions. An example of the \#StopDjihadism campaign by the French government had launched in January 2015 after the terror attacks on the Charlie Hebdo magazine offices and supermarkets in Paris. So, counter-narratives through online media or social media are effectively used as a preventive strategy against extremist sympathizers and they have not become active supporters. While for active supporters they may not pay attention to the counter-narrative messages or even take a stronger stance or other position than intended in this persuasive message.

\footnotetext{
${ }^{29}$ Jan-Jaap van Eerten et al., "Developing a Social Media Response to Radicalization: The Role of Counter-Narratives in Prevention of Radicalization and de-Radicalization" (WODC, 2017).

30 Alex P Schmid, “Al-Qaeda's 'Single Narrative' and Attempts to Develop CounterNarratives: The State of Knowledge," The Hague: ICCT 26, no. 2 (2014): 208-225.
}

JURNAL THEOLOGIA - Volume 31, Nomor 2, Desember 2020 
This research uses Walter Fisher's theory of narrative analysis. This theory believes that humans are storytellers, and consideration of values, emotions and aesthetics is the basis for human beliefs and behaviour. The five assumptions of Fisher's narrative theory, namely: ${ }^{31}$ (1) Basically, humans are storytellers. Humans with their stories try to convey something that is happening around them. A person can change their perspective, behaviour or attitude by listening to a story (message or information) from another person. (2) Decisions about a story based on sound or rational considerations. When someone listens to opposing stories, he will choose one of them, accept or reject, based on reasonable considerations, and according to his personal experiences or thoughts. (3) A rational considerants is determined by history, culture, biography, and character. Specific things can influence a person's choice and become a rational reason for them. It means that someone can be influenced by the context they are bound. (4) Rationality is based on someone's assessment of the truth and consistency of a story. Someone will believe the story if it looks believable and consistent. (5) Someone is in the story and must choose an existing story. So, he can experience life changes and can repeat life according to the selected story.

Based on the assumptions of Fisher's narrative theory, there are two key concepts, namely narrative and narrative rationality. First, the narrative includes verbal and non-verbal descriptions, according to the sequence of events, then given the meaning by the audience. The second, narrative rationality is the audience is given a parameter to measure narrative can be trusted or not, will be chosen or rejected. The concept of narrative rationality uses two principles: (1) Coherence, is an important standard for assessing narrative rationality. It refers to the internal consistency of a narrative, for example, the consistency of stories and characters. Then, coherence is based on three types, are: structural coherence (referring to the level of the elements of a story that flow well and smoothly), material coherence (referring to the level of congruence or linkage between a story and another), characterological coherence (referring to believable characters in the story); (2) Truth, is

31 Richard West and Lynn H Turner, "Pengantar Teori Komunikasi: Analisis Dan Aplikasi," Jakarta: Salemba Humanika, 2008, 46. 
assessing the credibility of a story. When a story conveys an accurate statement about social reality, there is the truth.

Besides using Fisher's narrative theory analysis, the Jean-Noel Kapferer's brand identity prism theory from management science can be adopted as a framework for deconstructing or countering radical-terrorist narratives. It is an effort to prevent radicalization and recruitment of new members. Extremist propaganda and radical ideology are packaged as interesting messages and channelled through digital media to influence and attract audience support and new members. It is branded products or a brand. ${ }^{32}$

Brand identity as a strategy to build and promote the uniqueness of a brand among other competing brands. There are six aspects to brand identity, including (1) Physique; aspects of the physical appearance of the brand or something that comes to the mind of consumers when the brand name is mentioned. In a narrative context, this is related to the main purpose of the narrative. (2) Personality; aspects of the personality as a brand character. In this context, the characters or figure in the narrative. (3) Culture; aspects of the value system and the basic principles inherent in the brand. This is related to the values in the narrative. (4) Relationship; aspects of the relationship between the brand and consumers or society. This is related to narrative interpretation in society. (5) Reflection, a reflection aspect that is represented by the brand in the minds of consumers. This is related to audience follow-up after reading the narrative. (6) Self-image, the image or internal description of the consumer. It's mean, how to see a narrative from the audience's point of view.

\section{Counter Narrative Message of Islami.co and Ruangobrol.id}

Islami.co is an online media site that has a vision of Islam rahmatan lil'alamin, Islam is a friendly, tolerant and moderate. Islami.co disseminates information and ideas to support the growth of tolerance and peaceful society. It is motivated by the fact that the cyberspace is filled with websites or social media accounts that contain provocations and hate sentiments so that it can

32 Philip Effiom Ephraim, "Cristina Archetti, Understanding Terrorism in the Age of Global Media: A Communication Approach," International Journal of Communication 9 (2015): 3.

JURNAL THEOLOGIA — Volume 31, Nomor 2, Desember 2020 
lead to violent conflicts for Indonesian Muslims. Islami.co exists as a form of counter-hegemony against full of provocation websites. This site is initiated and developed by millennial generation from pesantren (Islamic boarding school) graduates. The segmentation is adolescence to adulthood. Besides, it is also to reach ordinary people in urban areas. Islami.co exists as an alternative source of reference for people to studying Islam and more religious, not only one interpretation and not conservative. The contents of the rubrics are news, columns, Islam studies, stories, worship, lessons, wisdom and features. Furthermore, Islami.co also penetrates social media such as Facebook, Twitter, Instagram and Youtube. Since Islami.co was founded in 2013, until this article was written, content with the keywords "radicalism", "extremism" or "terrorism" was found around a thousand more contents.

The second, Ruangobrolid is an online media in the form of a website portal that has the aim of spreading the values of peace and tolerance, to prevent radicalism and terrorism. Ruangobrolid was initiated by Prasasti Production which is a production house that focused on issues of radicalism and terrorism. Prasasti Production cannot be separated from the Prasasti Perdamaian Foundation which is the main of this production house and has been doing P/CVE (Preventive/Counter Violence Extremism) since 2008. The contect of website or rubrics are about phenomena, creation, stories and reviews. The content is not only written form but also presented in the form of videos and stories or serials on social media (including Facebook, Twitter, Google+, Pinterest). The tagline is "dare to share", the meaning is to invite audiences or readers to dare to share, telling their stories and disseminate the information. The content of Ruangobrol.id is about the issues of radicalism and the current issues discussed in the community or society.

Islami.co and Ruangobrol.id have criteria in this study. They was focused and concerned to conveying counter-narrative of radicalism and targeting young people. Islami.co and Ruangobrol.id have differences are the background of the manager or administrator of Islami.co is Muslim and santri (graduates of Islamic boarding school student), and Ruangobrol.id is not only Muslim and santri. The segmentation of Islami.co is more about the Muslim community, and Ruangobrolid is for the general public. The majority of authors or interviewees in Islami.co are religious leaders, Muslim scholars, teachers, students or santri, and others. And then, the authors or interviewees 
in Ruangobrol.id are they who have been involved in radical groups, terrorists, ex-terror convicts, and others.

Furthermore, to find the rationality of the narrative created by Islami.co and Ruangobrol.id, it was analyzed using Fisher's narrative theory. First, structural coherence. The narrative structure of Islami.co and Ruangobrol.id has coherence between an element and another. The coherence can be described in the table below:

\begin{tabular}{|l|l|}
\hline \multicolumn{2}{|l|}{ Islami.co : Narration of "Religion with Love" } \\
\hline Physique & $\begin{array}{l}\text { Provide an understanding that Islam teaches about love, affection, } \\
\text { friendship, and not violence. Islam is a moderate religion, not } \\
\text { extreme and not exclusive. }\end{array}$ \\
\hline Reflection & $\begin{array}{l}\text { Everyone understands the teachings of Islam well and then } \\
\text { presents the values of goodness from religion to communicate } \\
\text { and interact with everyone of all religions. }\end{array}$ \\
\hline Self-image & $\begin{array}{l}\text { Radicalism and violence in the name of the religion still occur, and } \\
\text { become global issues. Radical group networks active in teaching } \\
\text { violence by brainwashing and do not want dialogue between } \\
\text { perspectives. }\end{array}$ \\
\hline $\begin{array}{l}\text { Culture/ } \\
\text { value }\end{array}$ & $\begin{array}{l}\text { The Holy Qur'an describes Islam as peace and compassion } \\
\text { religion and teaches every Muslim to have good relationships with } \\
\text { fellow humans. }\end{array}$ \\
\hline Islami.co: Narration of "Tolerance is active, not passive" \\
\hline Physique & $\begin{array}{l}\text { Provide an understanding that differences are sunnatullah } \\
\text { (Allah's decree) and tolerance must be kept and maintained to } \\
\text { create a peaceful life. }\end{array}$ \\
\hline Reflection & $\begin{array}{l}\text { Everyone has an active attitude of tolerance, which is based on a } \\
\text { shared spirit as a nation, according to the concept of } u k h u w a h \\
\text { maintain diversity in Indonesia. }\end{array}$ \\
\hline
\end{tabular}




\begin{tabular}{|l|l|}
\hline Self-image & $\begin{array}{l}\text { The various cases of intolerance based on religion are often } \\
\text { occurring in society. Intolerance can make disunity. Many people } \\
\text { are unconsciously led to intolerant actions that are deliberately } \\
\text { created by certain groups. }\end{array}$ \\
\hline $\begin{array}{l}\text { Culture/ } \\
\text { value }\end{array}$ & $\begin{array}{l}\text { The values from holy Qur'an refers to Islam is a religion of } \\
\text { rahmatan lil'alamin (mercy for all) and plurality society is a } \\
\text { blessing from Allah or sunnatullah. }\end{array}$ \\
\hline
\end{tabular}

\begin{tabular}{|c|c|}
\hline \multicolumn{2}{|c|}{ Ruangobrol.id : Narration of "From cool to slipping radical groups" } \\
\hline Physique & $\begin{array}{l}\text { Provide an understanding that everyone can enter the radicalism- } \\
\text { terrorism group, it is not for a single reason, but there are various } \\
\text { factors. }\end{array}$ \\
\hline Reflection & $\begin{array}{l}\text { Everyone, especially young people, must be critical of the } \\
\text { information received, the religious studies followed, be sensitive } \\
\text { to the surrounding environment (school, campus), and have } \\
\text { moderate religious references. }\end{array}$ \\
\hline Self-image & $\begin{array}{l}\text { Radical groups use technology and modern methods to carry out } \\
\text { their actions. Internet and social media as a medium to convey } \\
\text { their propaganda, seek sympathizers and recruitment members. }\end{array}$ \\
\hline $\begin{array}{l}\text { Culture/ } \\
\text { value }\end{array}$ & $\begin{array}{l}\text { Individuals who are involved in the radicalism-terrorism process } \\
\text { have experience 'religious seeking', moral self-improvement, } \\
\text { internalization of exclusive religious values, and the struggle for } \\
\text { jihad. }\end{array}$ \\
\hline \multicolumn{2}{|c|}{ Ruangobrol.id : Narration of "Tolerance from childhood" } \\
\hline Physique & $\begin{array}{l}\text { Provide an understanding of how to build positive views } \\
\text { regarding religious and ethnic differences, especially in a } \\
\text { homogeneous environment. Tolerance is key for builds } \\
\text { togetherness and unity. }\end{array}$ \\
\hline Reflection & $\begin{array}{l}\text { Understanding and practising tolerance with simple things from } \\
\text { an early age, at home, school, and the surrounding environment } \\
\text { to avoid intolerance and discrimination. }\end{array}$ \\
\hline
\end{tabular}




\begin{tabular}{|l|l|}
\hline Self-image & $\begin{array}{l}\text { There is a group interest, both economically and politically, to } \\
\text { spread hatred between religions and it can lead to conflict and } \\
\text { disunity. }\end{array}$ \\
\hline $\begin{array}{l}\text { Culture/ } \\
\text { value }\end{array}$ & $\begin{array}{l}\text { The values of tolerance have been embedded in Indonesian } \\
\text { society for a long time. Even Indonesia stands based on diversity. }\end{array}$ \\
\hline
\end{tabular}

Second, analysis of material coherence is the relationship between the narrative was created by Islami.co and Ruangobrol.id.

\begin{tabular}{|l|l|}
\hline \multicolumn{2}{|l|}{ Islami.co } \\
\hline $\begin{array}{l}\text { Related } \\
\text { narrative }\end{array}$ & $\begin{array}{l}\text { A narrative was created based on Islamic studies or pesantren } \\
\text { culture and the point of view of religious leaders, that Islam is } \\
\text { moderate and tolerant, does not teach violence, radicalism and } \\
\text { terrorism. }\end{array}$ \\
\hline $\begin{array}{l}\text { Relation- } \\
\text { ship }\end{array}$ & $\begin{array}{l}\text { Developing community life filled with tolerance and peace, thus } \\
\text { bringing Indonesia to become a strong nation in unity. }\end{array}$ \\
\hline $\begin{array}{l}\text { Audience } \\
\text { condition }\end{array}$ & $\begin{array}{l}\text { Many groups carry out provocations and hateful sentiments in the } \\
\text { name of religion and lead to violent conflicts for Indonesian } \\
\text { Muslims. }\end{array}$ \\
\hline Ruangobrol.id \\
\hline $\begin{array}{l}\text { Related } \\
\text { narrative }\end{array}$ & $\begin{array}{l}\text { Creating narratives based on the life experiences from someone } \\
\text { who's been involved in intolerant action, radicalism, and } \\
\text { terrorism. It is an important lesson for others. And then } \\
\text { differences in society must be addressed wisely and have a } \\
\text { positive view. }\end{array}$ \\
\hline $\begin{array}{l}\text { Relation- } \\
\text { ship }\end{array}$ & $\begin{array}{l}\text { Everyone must understand each other and appreciates } \\
\text { differences. The values of peace and tolerance must be spread to } \\
\text { prevent acts of radicalism and terrorism. }\end{array}$ \\
\hline $\begin{array}{l}\text { Audience } \\
\text { condition }\end{array}$ & $\begin{array}{l}\text { There are interest groups who spread hatred between religions } \\
\text { (interfaith) deliberately and can lead to conflict and disunity. }\end{array}$ \\
\hline
\end{tabular}


Third, analysis of characterological coherence is the characters or figures in the narrative to convince or persuade the audience.

\begin{tabular}{|c|c|}
\hline Topics & Personality (Characters in the Narrative) \\
\hline \multicolumn{2}{|l|}{ Islami.co } \\
\hline $\begin{array}{l}\text { "Religion } \\
\text { with Love" }\end{array}$ & $\begin{array}{l}\text { Prophet Muhammad SAW introduced Islam as a tolerant religion, } \\
\text { for Muslim and other religions. The Prophet also never taught } \\
\text { violence or oppression to different faiths, but we must appreciate } \\
\text { and respect the differences. }\end{array}$ \\
\hline $\begin{array}{l}\text { "Tolerance } \\
\text { is active, } \\
\text { not } \\
\text { passive" }\end{array}$ & $\begin{array}{l}\text { There are some figures in this narrative, KH. Hasyim Asy'ari and } \\
\text { KH. Wahid Hasyim. They were educated through pesantren } \\
\text { culture and participated input the foundation of diversity in } \\
\text { Indonesia. Gus Dur (KH. Abdurrahman Wahid) as the figure had } \\
\text { a tolerant, democratic, pluralist attitude, and upheld diversity. }\end{array}$ \\
\hline \multicolumn{2}{|c|}{ Ruangobrol.id } \\
\hline $\begin{array}{l}\text { "From cool } \\
\text { to slipping } \\
\text { radical } \\
\text { groups" }\end{array}$ & $\begin{array}{l}\text { Ex-terrorist convict who joined the radical group network } \\
\text { because of the offer of a humanitarian movement. He is lucky can } \\
\text { get out from radical groups with strong efforts and } \\
\text { determination. It is not an easy matter to get out of the doctrines } \\
\text { of radicalism and terrorism. }\end{array}$ \\
\hline $\begin{array}{l}\text { "Tolerance } \\
\text { from } \\
\text { childhood" }\end{array}$ & $\begin{array}{l}\text { A person who has experienced an intolerant phase. He looks } \\
\text { everything from one perspective, has a narrow view of } \\
\text { differences (especially religion). Then, he changes to be more } \\
\text { tolerant, respect religious differences, and adaptable to } \\
\text { multiculturalism. }\end{array}$ \\
\hline
\end{tabular}

Furthermore, analysis of the truth (narrative alignment) is consistency between the narrative and the vision, mission and activities of digital media to prevent radicalism. 


\section{Islami.co}

1. Islami.co takes tagline as enlightening and friendly Islamic digital media. Its means Islami.co as a source of reference for the public in studying Islam and being more religious and supporting the growth of tolerance and peaceful society.

2. The content of Islami.co describes Islam which is contemporary, moderate, and not conservative.

3. The content describes the stories of the Prophet Muhammad, friends, scholars, guardians, pious people to be role models for the public.

\section{Ruangobrol.id}

1. Ruangobrol.id has a tagline "dare to share". The audience can also see the wider world because the audience often narrows their mind due to not having time to look around.

2. The content raised is related to phenomena, stories or experiences of someone in the circles of intolerance, radicalism, extremism and terrorism.

3. The main foundation conducts workshops or training to counter the issue of extremism, hate speech, and assists young people to create positive content campaigns in digital media, etc.

The description of the four narratives above can be concluded that Islami.co and Ruangobrol.id have a purpose to conveyed messages to the public that Islam is a religion of love and without violence. Furthermore, Islami.co and Ruangobrol.od conveyed the message that Indonesia is a diverse country, upholds differences and strengthens tolerance. The narratives aim to counter the global jihadist narratives which argue that: (1) Islam is being attacked by the west-country under the command of the United States; (2) The Mujahideen who are called "terrorists", are defending themselves from attacks and they are fighting for the oppressed Muslims; (3) Jihad for radical groups in defending Islam is appropriate and justified by religion; and (4) the obligation for Muslims to support jihad actions. ${ }^{33}$

33 Christian Leuprecht et al., "Narratives and Counter-Narratives for Global Jihad: Opinion versus Action," Countering Violent Extremist Narratives, 2010, 58-71. 
Based on the narrative analysis and theoretical discussion above, it is known that the narratives were created by Islami.co and Ruangobrol.id has narrative rationality as a parameter to measure and evaluate that the narratives are accepted and trusted by the audience or public. First, structural coherence can be seen from the narrative or story that is conveyed flowing well and smoothly, so that many audiences read the narrative and give positive responses. Second, material coherence can be seen from the existence of congruence or linkages between a story and another to counter the issues of radicalism. Many story or narrative has the same meaning, teaching, and learning. Third, characterological coherence can be seen from the characters that can be trusted in the narrative or story that is conveyed, as like the prophet Muhammad, Gusdur, and ex-terrorist convict. Fourth, the truth of narrative can be seen that the narrative was created is appropriate with the vision, mission of media digital and program or activities that have been carried out by Islami.co and Ruangobrol.id.

The narrative was created by Islami.co and Ruangobrol.id is a brand that is offered to the public by using identity prism analysis to counter radicalism narratives. The narrative is built contains six aspects, including physical aspects, seen from the main purpose of the narrative, is to build a narrative of peace and tolerance in a difference and diversity. Second, aspect of personality, the narration is strengthened by the presence of a convincing character, such as the Prophet Muhammad SAW as the best human being. Third, the cultural aspect, each narrative has values that can be internalized by audiences in life, as like, values of peace and diversity. Fourth, the aspect of the relationship, there is a relation between people as citizens to create tolerance or harmony to create a peaceful country. Fifth, the reflection aspect, there is an expectation for the audience to understand the content of the narrative and practice it in everyday life. Sixth, the self-image aspect, the public is seen to be sensitive and can read the situation that there are groups that spread hatred and can be trigger conflicts and splits or disunity because of radical, extreme, and terror acts.

After integrating the two theoretical concepts into the narratives, it was found that the narratives of the two digital media, Islami.co and Ruangobrol.id, was created to counter the narrative of radicalism that had been constructed by radical and extreme groups structurally, systematically, and massively. 
There is the difference from Islami.co and Runagobrol.id is segmentation and positioning. The segmentation of Islami.co is for Islamic groups, adolescents to adults, and rural and urban areas. And than Ruangobrol.id has segmented all religions, youth, and for urban areas.

Furthermore, digital media positioning is very important to differentiate between a media and another and give benefits for the audience. The uniqueness of the brand can be seen. Islami.co has positioned as an online medium that is present as a reference for Muslims to seek moderate religious sources or materials. The content is packaged in an attractive and easy to understand way for ordinary people who want to learn about Islam. And than Ruangobrol.id positioned as a public media and sharing media, for all religions in spreading the values of tolerance and anti-radicalism. So, the counternarrative of radicalism becomes a communication strategy to strengthen the brands for Islami.co and Ruangobrol.id.

The counter-narrative of radicalism is an important communication strategy that must be carried out amidst a lot of narratives constructed by radical, extreme, and terrorist groups through internet networks and social media platforms. Because actions that lead to intolerance, violence, or radicalism can trigger conflict and break national unity or disunity. This is also in line with the commitment of the Indonesian government to seriously tackle radicalism with the existence of the National Counterterrorism Agency (BNPT) and various terrorism prevention programs from ministries and institutions. In the digital era, the content of counter-narrative of radicalism must be intensified and supported. If we refer to the prism of identity theory, the counter-narrative of radicalism is produced must be able to become a strong brand and have coherence and consistency.

\section{Conclusion}

The phenomenon of searching for information or knowledge about religion through the internet and social media represents the condition of today's digital society. This condition becomes the strategic ground for moderate groups or media to create a counter-narrative of radicalism massively. Communication strategies to deliver counter-narrative messages must be created effectively. Messages can be constructed softly to reject or 
counter the narrative of radicalism and then frame the narrative of moderatism. It will make the public more empowered against cyber radicalism. Besides, the existence of moderate groups in the cyberspace will be a power or force to move their followers. Therefore, the counter-narrative of radicalism must be a common mission and digital movement involving various elements. The elements are government, community organizations, educational institutions, media institutions, and individuals (influencers) to campaign for Islam rahmatan lil'almin and Indonesia as diverse and tolerant country.

\section{BIBLIOGRAPHY}

Alarid, Maeghin. "Recruitment and Radicalization: The Role of Social Media and New Technology." Impunity: Countering Illicit Power in War and Transition, 2016, 313-30.

Archetti, Cristina. "The Al Qaeda Narrative as a Brand." In Understanding Terrorism in the Age of Global Media, 144-68. Springer, 2013.

Ashour, Omar. "Online De-Radicalization? Countering Violent Extremist Narratives: Message, Messenger and Media Strategy." Perspectives on Terrorism 4, no. 6 (2010): 15-19.

Bakti, Agus Surya. Deradikalisasi Dunia Maya: Mencegah Simbiosis Terorisme Dan Media. Daulat Press, 2016.

BNPT. "Waspadai Aktivitas Terorisme Di Ruang Siber," 2020. https://bnpt.go.id/waspadai-aktivitas-terorisme-di-ruang-siber-deputibidang-penindakan-dan-pembinaan-kemampuan-bnpt-sepakatiperjanjian-kerja-sama-dengan-direktorat-jenderal-aplikasi-informatikakemkominfo.

Briggs, Rachel, and Sebastien Feve. "Review of Programs to Counter Narratives of Violent Extremism," 2013.

Campbell, Heidi. When Religion Meets New Media. New York: Routledge, 2010.

Conway, Maura. "Determining the Role of the Internet in Violent Extremism and

Terrorism: Six Suggestions for Progressing Research.” Studies in Conflict \& 
Terrorism 40, no. 1 (2017): 77-98.

Eerten, Jan-Jaap van, Bertjan Doosje, Elly Konijn, B A de Graaf, and Mariëlle de Goede. "Developing a Social Media Response to Radicalization: The Role of Counter-Narratives in Prevention of Radicalization and de-Radicalization." WODC, 2017.

Epafras, Leonard. "Religious E-Xpression among the Youths in the Indonesian Cyberspace," 2016.

Ephraim, Philip Effiom. "Cristina Archetti, Understanding Terrorism in the Age of Global Media: A Communication Approach." International Journal of Communication 9 (2015): 3.

Fairclough, Norman. Analysing Discourse: Textual Analysis for Social Research. New York: Routledge, 2003.

Ghifari, Iman Fauzi. “Radikalisme Di Internet." Religious: Jurnal Studi Agama-Agama Dan Lintas Budaya 1, no. 2 (2017): 123-34.

Grossman, Michele. "Disenchantments: Counterterror Narratives and Conviviality." Critical Studies on Terrorism 7, no. 3 (2014): 319-35.

Holbrook, Donald. "What Types of Media to Terrorists Collect?: An Analysis of Religious, Political and Ideological Publications Found in Terrorism Investigations in the UK." ICCT Research Paper, 2017.

Huda, Achmad Zainal. "Melawan Radikalisme Melalui Kontra Narasi Online." Journal of Terrorism Studies 1, no. 2 (2019): 1.

Hui, Jennifer Yang. "The Internet in Indonesia: Development and Impact of Radical Websites." Studies in Conflict \& Terrorism 33, no. 2 (2010): 171-91.

INFID (International NGO Forum on Indonesian Development). Urgensi Dan Strategi Efektif Pencegahan Ekstrimisme Di Indonesia. Jakarta: INFID, 2018.

Kapferer, J N. “Brand Identity Prism.” Strategic Brand Management, 2006, 154-55.

Kominfo. "Pemblokiran Dan Literasi Jadi Langkah Kominfo Cegah Terorisme Di Ruang Digital," 2020. https://aptika.kominfo.go.id/2020/08/pemblokirandan-literasi-jadi-langkah-kominfo-cegah-terorisme-di-ruang-digital/.

Leuprecht, Christian, Todd Hataley, Sophia Moskalenko, and Clark McCauley. "Narratives and Counter-Narratives for Global Jihad: Opinion versus Action." Countering Violent Extremist Narratives, 2010, 58-71. 
Miskimmon, Alister, Ben O'Loughlin, and Laura Roselle. Forging the World: Strategic Narratives and International Relations. University of Michigan Press, 2017.

Perešin, Anita. "Al-Qaeda Online Radicalization and the Creation of Children Terrorists." Medijska Istraživanja: Znanstveno-Stručni Časopis Za Novinarstvo i Medije 20, no. 1 (2014): 85-101.

Rahman, Fazlul. "Kekerasan Atas Nama Tuhan: Respons" Netizen" Indonesia." Jurnal Indo-Islamika 1, no. 2 (2012): 197-231.

RivanieParawansa, Syarif Saddam, and Toetik Rahayuningsih Koesrianti. "Prevention of Radicalism in the Cyberspace in Indonesia." International Journal of Humanities Social Sciences and Education (IJHSSE) 6, no. 7 (2019): 63-72.

Sari, Benedicta Dian Ariska Candra. "Media Literasi Dalam Kontra Propaganda Radikalisme Dan Terorisme Melalui Media Internet." Peperangan Asimetrik 3, no. 1 (2017).

Sarwono, Sarlito Wirawan. Terorisme Di Indonesia: Dalam Tinjauan Psikologi. Pustaka Alvabet, 2012.

Schmid, Alex P. “Al-Qaeda's 'Single Narrative' and Attempts to Develop CounterNarratives: The State of Knowledge." The Hague: ICCT 26, no. 2 (2014): 20825.

Seib, Philip, and Dana M Janbek. Global Terrorism and New Media: The Post-Al Qaeda Generation. New York: Routledge, 2010.

Usman, Sunyoto, Zuly Qodir, and J Hasse. Radikalisme Agama Di Indonesia. Yogyakarta: Pustaka Pelajar, 2014.

Weimann, Gabriel. Terror on the Internet: The New Arena, the New Challenges. US Institute of Peace Press, 2006.

West, Richard, and Lynn H Turner. "Pengantar Teori Komunikasi: Analisis Dan Aplikasi." Jakarta: Salemba Humanika, 2008.

Winarni, Leni. "Media Massa Dan Isu Radikalisme Islam." Jurnal Komunikasi Massa 7, no. 2 (2014): 159-66. 